\title{
Expanded access with intravenous hydroxypropyl- $\beta$-cyclodextrin to treat children and young adults with Niemann- Pick disease type C1: a case report analysis
}

Caroline Hastings ${ }^{1,2^{*}}$ (D), Camilo Vieira ${ }^{3}$, Benny Liu ${ }^{4,5}$, Cyrus Bascon ${ }^{1}$, Claire Gao ${ }^{6,7}$, Raymond Y. Wang ${ }^{8,9}$, Alicia Casey ${ }^{10}$ and Sharon Hrynkow ${ }^{11}$

\begin{abstract}
Background: Niemann-Pick Disease Type C (NPC) is an inherited, often fatal neurovisceral lysosomal storage disease characterized by cholesterol accumulation in every cell with few known treatments. Defects in cholesterol transport cause sequestration of unesterified cholesterol within the endolysosomal system. The discovery that systemic administration of hydroxypropyl-beta cyclodextrin (HPBPD) to NPC mice could release trapped cholesterol from lysosomes, normalize cholesterol levels in the liver, and prolong life, led to expanded access use in NPC patients. HPßCD has been administered to NPC patients with approved INDs globally since 2009.

Results: Here we present safety, tolerability and efficacy data from 12 patients treated intravenously (IV) for over 7 years with HP $\beta C D$ in the US and Brazil. Some patients subsequently received intrathecal (IT) treatment with HP $\beta C D$ following on average 13 months of IV HP $\beta C D$. Several patients transitioned to an alternate HP $\beta C D$. Moderately affected NPC patients treated with HPBCD showed slowing of disease progression. Severely affected patients demonstrated periods of stability but eventually showed progression of disease. Neurologic and neurocognitive benefits were seen in most patients with IV alone, independent of the addition of IT administration. Physicians and caregivers reported improvements in quality of life for the patients on IV therapy. There were no safety issues, and the drug was well tolerated and easy to administer.

Conclusions: These expanded access data support the safety and potential benefit of systemic IV administration of $H P \beta C D$ and provide a platform for two clinical trials to study the effect of intravenous administration of HP $\beta C D$ in NPC patients.
\end{abstract}

Keywords: Niemann-pick disease type C, Hydroxypropyl-beta-cyclodextrin, Intravenous administration, Investigational new drug, hepatomegaly, splenomegaly, lung disease

\section{Introduction}

Niemann-Pick disease, Type C (NPC) is a pan-ethnic, often fatal, autosomal recessive lysosomal storage disease characterized clinically by peripheral organ dysfunction, psychiatric manifestations, and neurodegeneration $[1,2]$. Reported incidence is approximately 1 in 90,000-120,000

\footnotetext{
* Correspondence: caroline.hastings@ucsf.edu

'Department of Pediatric Hematology Oncology, UCSF Benioff Children's Hospital Oakland, 747 52nd Street, Oakland, CA 94609-1809, USA

${ }^{2}$ Department of Pediatrics, University of California San Francisco, San

Francisco, CA, USA

Full list of author information is available at the end of the article
}

[3-6]. Loss of function mutations in the NPC1 or NPC2 genes cause a cholesterol transport defect which results in the accumulation of lipids (cholesterol, sphingomyelin, sphingosine and glycosphingolipids) within the endosome. Toxic accumulation of cholesterol and these other lipids are responsible for the clinical features of the disease [1, 7-13]. The symptoms associated with NPC vary with the age of onset. These include visceral manifestations (organomegaly, liver and lung dysfunction), a movement disorder (cerebellar ataxia), problems with fine motor manipulation (dystonia, dysmetria), and

(C) The Author(s). 2019 Open Access This article is distributed under the terms of the Creative Commons Attribution 4.0 International License (http://creativecommons.org/licenses/by/4.0/), which permits unrestricted use, distribution, and 
speech and swallowing (dysarthria and dysphagia). Impaired vertical supranuclear saccades, often leading to complete supranuclear gaze palsy (VSGP), is also a key clinical feature and one of the earliest and most frequently noted signs by patient families and physicians. Impairment of vertical saccades occurs early in the disease and development and slowing of horizontal saccades correlate with disease progression and possibly severity and may be an important risk indicator [14-20]. Seizures as well as cataplexy are frequent in patients with progressive neurologic decline [21-23]. Progressive developmental delay and altered memory and cognition are present in many patients. A range of behavioral and/ or psychiatric disorders including psychosis, bipolar disease, and attention deficit may be apparent as initial or later manifestations of NPC [1, 5, 14, 24-26].

Diagnosis of NPC is often delayed due to the highly heterogeneous clinical phenotypes, likely due to genotypic polymorphism [24, 25, 27], coupled with lack of awareness of the disease amongst clinicians [19-21]. NPC may present at any age, from the perinatal period up to even the sixth or seventh decade of life $[1,16,28-31]$. Most patients diagnosed with the condition die between 10 and 25 years of age [1, 5, 24].

\section{Natural history of systemic manifestations of NPC}

NPC is classified as a neurovisceral disorder and the neurologic, psychiatric or visceral signs may arise independently of one another and follow a different course of progression [1]. Patients presenting in infancy to early childhood typically have isolated hepatosplenomegaly, which may stay isolated for many years. Older children and adolescents frequently will have splenomegaly either as an isolated early finding on physical exam or the inaugural sign of the disease [1]. Splenomegaly may resolve in patients when neurological symptoms develop or later, but typically $80-90 \%$ of patients will have evidence of organomegaly $[3,16]$.

The severity of neurocognitive involvement often defines the projected outcome, but is typically preceded by signs or symptoms of systemic disease. In a recent epidemiologic study of 53 patients with NPC in the United Kingdom, 17 (32\%) had a systemic presentation [24]. Systemic manifestations include neonatal cholestatic jaundice, sometimes progressing to fulminant liver failure, transient jaundice in the newborn period, isolated hepatomegaly or splenomegaly or both, and/or evidence of hypersplenism (decreased blood counts such as thrombocytopenia, leukopenia, or anemia related to enlarged spleen size) $[1,14,24,32,33]$. NPC should be strongly suspected in the neonate with cholestasis [34] and is one of several inherited metabolic disorders to be a recognized cause of fatal acute liver failure in the newborn or young child [35]. Though the majority of infants will experience early resolution of jaundice, the organomegaly often remains for a variable period of time and precedes onset of neurologic manifestations. Children with fulminant and rapidly progressive liver disease (approximately $10 \%$ of those with cholestasis) typically die within the first 6 months of life and some have undergone liver transplantation [24]. Our report includes a young patient with evidence of severe liver disease who responded favorably to IV $\mathrm{HP} \beta C D$ with decreasing liver size and improved synthetic function.

As the defect in the NPC protein affects every cell of the body it can be assumed all organs would be affected, though not all organs show evidence of irreversible damage or overt clinical significance. Lung disease is extremely rare in NPC, though the pathologic features are not well characterized and it is more prevalent in patients with $N P C 2$ as compared to NPC1 [36]. Patients with primary lung involvement show evidence of interstitial lung disease with thickened septa, foamy macrophages and infiltrative leukocytes [37]. A restrictive pattern is evident on pulmonary function testing. Patients with severe neurologic manifestations, with or without lung disease, can develop recurrent aspiration pneumonias, resultant hypoxia and chronic lung disease [38].

Current treatment options for patients with NPC are limited to supportive care measures and the use of miglustat (N-butyl-deoxynojirimycin, Zavesca ${ }^{\circ}$ ), the only disease specific agent approved for the treatment of neurological manifestations of NPC by the European Medicines Agency in 2009. It is not currently FDA approved for use in the United States for this indication $[3,39-46]$. Observations from cohort studies and NPC registries suggest miglustat has an impact on stabilization of neurologic symptoms, an effect that appears most pronounced in the juvenile and adult onset groups [20, 39, 41, 42, 44, 47]. Miglustat appears to have no impact on organomegaly or systemic manifestations of disease [20]. The international disease registry for Niemann Pick type $\mathrm{C}$ provides the largest data base to date for assessment of safety and response to intervention, with $69 \%$ of patients demonstrating improvement/stability utilizing composite disability scores in patients who received continuous miglustat for an average period of 2 years [39]. Assessment of retrospective data collected in registries is subject to variable collection practices, and the low numbers of untreated patients limits conclusions of the effect of miglustat versus standard of care on outcomes. Current licensed options for disease modification are inadequate to address the heterogeneity of the disease including the disease effect on the brain and peripheral organs.

One emerging therapeutic that may target the systemic and neurologic features of NPC is hydroxypropyl- $\beta$ cyclodextrin (HP $\beta C D)$. HP $\beta C D$ is a cyclic oligosaccharide 
consisting of seven glucopyranose units, with a hydrophilic exterior and a hydrophobic interior, thus enhancing the solubility of poorly water-soluble compounds (such as cholesterol) via formation of compound-cyclodextrin complexes [48]. As such, HP $\beta C D$ has been utilized as an excipient facilitating transport of molecules across membranes [49]. Early studies in NPC mice testing allopregnanolone complexed with $\mathrm{HP} \beta C D$ demonstrated prolongation of lifespan [50-52]. The first studies involving NPC mice confirming $\mathrm{HP} \beta C D$ alone delivered systemically was responsible for the beneficial effects on cholesterol metabolism, decreasing total body cholesterol burden, and ameliorating neurological symptoms, opened new therapeutic avenues for NPC patients [53-57]. The first clinical protocol (2009-2010 Hastings/Hempel protocol and FDA reports available online) [58] was developed based on the initial discovery of the positive effects of HPBCD on the NPC mouse model by Dr. Benny Liu at the University of Texas Southwestern, in the lab of Dr. John Dietschy [53]. Prolonged lifespan and clinical benefit were confirmed in subsequent studies following the administration of $\mathrm{HP} \beta C D$ to mouse and feline models of NPC disease [59-61].

We report here a series of 12 case histories of individuals with NPC who have either received intravenous (IV) $\mathrm{HP} \beta C D$ only or IV followed by concurrent IV and intrathecal (IT) HP $\beta C D$ (herein referred to as sequential or SEQ). The investigators utilized the original Hastings/ Hempel protocol for treatment and monitoring guidelines. Some investigators chose to modify the protocol with respect to dosage and/or intervals, as detailed in this report. Two formulations of HPBCD were used, Trappsol $^{\circ} \mathrm{Cyclo}^{\mathrm{Tu}}$ and Kleptose ${ }^{\circ}$. Nine of the patients received $\mathrm{Trappsol}^{\circ} \mathrm{Cyclo}^{\mathrm{Tm}}$ beginning in 2009, four exclusively, and five received this formulation initially followed by a change to Kleptose ${ }^{\bullet} \mathrm{HP} \beta C D$. For patients receiving both formulations, the vast majority of their experience with $\mathrm{HP} \beta \mathrm{CD}$ was with $\mathrm{Trappsol}^{\circ} \mathrm{Cyclo}^{\mathrm{Tw}}$. Three patients received Kleptose ${ }^{\circ}$ exclusively. The earliest use of Kleptose ${ }^{\bullet}$ was in 2013, when a compounded formulation became available. The FDA allowed interchange of these two products for patients receiving compassionate use $\mathrm{HP} \beta C D$ for NPC and they are therefore referred to only as HP $\beta C D$ in this publication.

\section{Methods}

The patient families and principal investigators utilizing the Hastings/Hempel expanded access protocol (or adaptation thereof) for IV HP $\beta C D$ were contacted by the authors $(\mathrm{SH}$ and $\mathrm{CH})$ to participate in a data collection protocol. A data acquisition protocol was developed by the lead author $(\mathrm{CH})$ and investigators sought approval from local ethics or Institutional Review Boards. Case Report Forms (CRFs) were developed to capture patient characteristics including manifestations of disease, adverse events (AEs), details of drug administration, laboratory and clinical assessments.

Informed consent was obtained from all of the subjects prior to the initiation of treatment with $\mathrm{HP} \beta C D$ in accordance to the local Institutional Review Boards and principles of ethical research according to the Declaration of Helsinki [62]. Further consent was obtained from the patient families to participate in the data acquisition protocol.

The original Hastings/Hempel protocol was developed in 2008 and granted Investigational New Drug (IND) approval [Hastings C. Compassionate Use of Hydroxypropyl- $\beta$-cyclodextrin in Identical Twins Suffering from Niemann Pick Type C; IND 104,114 and IND 104,116; submitted to FDA December 1, 2008]. This protocol was utilized internationally by 2009 and included assessments for safety with laboratory and clinical assessments. The first U.S. patients (SEQ 1,2) treated on this protocol initiated intravenous dosing at $80 \mathrm{mg} / \mathrm{kg} /$ hour for 4 days as a continuous infusion over 4 days, then transitioned to biweekly dosing over $8 \mathrm{~h}$, reaching a maximum of $2800 \mathrm{mg} /$ $\mathrm{kg} / \mathrm{dose}$. Pharmacokinetic data obtained at a dose of 2500 $\mathrm{mg} / \mathrm{kg}$ IV weekly (data not shown) were submitted to the FDA for review and serum concentrations approximated effective tissue concentration levels (target between 1 and $3 \mathrm{mM}$ ), the concentration at which prior mouse studies $\mathrm{HP} \beta C D$ was shown to act as a cholesterol shuttle, transporting cholesterol between membranes. [34, 54, 58, 63] High cellular concentrations $(10-100 \mathrm{mM})$ were avoided, in which $\mathrm{HP} \beta C D$ is known to serve as a cholesterol sink and can extract cholesterol from cellular membranes resulting in cell membrane damage and toxicity [64]. Further, animal studies confirmed a dose limited effect [65, 66]. These PK studies provided the earliest data in determining dosing and intervals for the shared protocol. Intrathecal dosing began 18 months later in these patients, in 2010, at an initial dose of $175 \mathrm{mg}$ every 2 weeks. The dose was increased to $350 \mathrm{mg}$ after a 3-month treatment and safety assessment period. SEQ patients 3,4,5,6 and 9 have followed the protocol as of the 2010 dosing protocol. Pharmacokinetic data were obtained to determine CSF drug concentrations to approximate those observed in the in vitro and in vivo mouse studies (data not shown). Other investigators utilizing this protocol initiated dosing at the same levels and some chose to dose escalate (dosing summarized in Table 1).

A number of clinical assessment scales to assess severity and progression of disease in NPC have been utilized to monitor and measure clinical manifestations longitudinally over time, and in response to intervention [41, 43, 44, 67]. In 2010, a clinical severity score (adapted from prior clinical tools [67] was published by the National Institutes of Health (NIH) in conjunction with the NPC natural history study to assess progression of disease (primarily neurocognitive); and 
Table 1 Clinical manifestations, HPßCD treatment data and adverse events

\begin{tabular}{|c|c|c|c|c|c|c|c|}
\hline $\begin{array}{l}\text { Patient } \\
\text { identification }\end{array}$ & $\begin{array}{l}\text { Age at } \\
\text { start of IV } \\
\text { HPßCD } \\
\text { treatment }\end{array}$ & $\begin{array}{l}\text { Symptom progression } \\
\text { at start of IV treatment }\end{array}$ & $\begin{array}{l}\text { Intravenous } \\
\text { treatment } \\
\text { Dose/Interval; } \\
\text { Length of } \\
\text { treatment }\end{array}$ & $\begin{array}{l}\text { Time } \\
\text { interval } \\
\text { between } \\
\text { start of IV } \\
\text { and IT } \\
\text { HPßCD } \\
\text { treatment }\end{array}$ & $\begin{array}{l}\text { Intrathecal treatment } \\
\text { Dose/Interval; Length of } \\
\text { treatment }\end{array}$ & $\begin{array}{l}\text { Adverse } \\
\text { effects, IV } \\
\text { HPßCD }\end{array}$ & $\begin{array}{l}\text { Adverse effects, IT } \\
\text { HP } \beta C D\end{array}$ \\
\hline SEQ1 & 5 years & $\begin{array}{l}\text { Ataxia, VSGP, loss of } \\
\text { language, dysphagia, } \\
\text { global developmental } \\
\text { delay }\end{array}$ & $\begin{array}{l}80 \mathrm{mg} / \mathrm{kg} / \mathrm{day} \\
\text { to } 2800 \mathrm{mg} / \mathrm{kg} \\
\text { twice weekly; } \\
\text { stable at } 2500 \\
\text { mg Q2 weeks; } \\
92 \text { months }\end{array}$ & $\begin{array}{l}18 \\
\text { months }\end{array}$ & $\begin{array}{l}175 \text { mg every } 2 \text { weeks; } \\
\text { advanced to } 350 \mathrm{mg} \\
\text { every } 2 \text { weeks (IO } 50 \mathrm{mg} \\
\text { substituted); } 74 \text { months }\end{array}$ & None & $\begin{array}{l}\text { Seizures, increased } \\
\text { frequency } 24 \mathrm{~h} \text { post IT }\end{array}$ \\
\hline SEQ2 & 5 years & $\begin{array}{l}\text { Ataxia, VSGP, loss of } \\
\text { language, dysphagia, } \\
\text { global developmental } \\
\text { delay }\end{array}$ & $\begin{array}{l}80 \mathrm{mg} / \mathrm{kg} / \mathrm{day} \\
\text { to } 2800 \mathrm{mg} / \mathrm{kg} \\
\text { twice weekly; } \\
\text { stable at } 2500 \\
\text { mg Q2 weeks; } \\
92 \text { months }\end{array}$ & $\begin{array}{l}18 \\
\text { months }\end{array}$ & $\begin{array}{l}175 \text { mg Q2weeks; } \\
\text { advanced to } 350 \mathrm{mg} \\
\text { every } 2 \text { weeks (IO } 50 \mathrm{mg} \\
\text { substituted); } 74 \text { months }\end{array}$ & None & $\begin{array}{l}\text { Seizures, increased } \\
\text { frequency } 24 \mathrm{~h} \text { post IT; } \\
\text { Intracranial hemorrhage } \\
\text { secondary to Ommaya } \\
\text { insertion, removal of } \\
\text { Ommaya }\end{array}$ \\
\hline SEQ3 & 15 years & $\begin{array}{l}\text { VSGP, progressive } \\
\text { cognitive impairment, } \\
\text { seizures, fine motor } \\
\text { coordination, psychosis, } \\
\text { ataxia }\end{array}$ & $\begin{array}{l}1200 \mathrm{mg} / \mathrm{kg} \\
\text { with increase } \\
\text { over } 8 \text { months } \\
\text { to } 2500 \mathrm{mg} / \mathrm{kg} \\
\text { weekly; } 83 \\
\text { months }\end{array}$ & $\begin{array}{l}16 \\
\text { months }\end{array}$ & $\begin{array}{l}175 \mathrm{mg} \text { (advanced to } \\
\text { max } 875 \mathrm{mg} \text { ), then } \\
\text { stabilized at } 350 \mathrm{mg} \text { Q15 } \\
\text { days; } 10100 \text { to } 350 \mathrm{mg} \\
\text { every } 15 \text { days prior to } \\
\text { removal at } 10 \text { months; } \\
67 \text { months }\end{array}$ & $\begin{array}{l}\text { Port-a-Cath } \\
\text { infection } \\
\text { (twice), } \\
\text { removal after } \\
\text { 2nd infection }\end{array}$ & $\begin{array}{l}\text { Meningitis, removal of } \\
\text { Ommaya }\end{array}$ \\
\hline SEQ4 & 11 years & $\begin{array}{l}\text { VSGP, progressive } \\
\text { cognitive impairment, } \\
\text { seizures, fine motor } \\
\text { coordination, psychosis, } \\
\text { ataxia, gelastic cataplexy }\end{array}$ & $\begin{array}{l}1200 \mathrm{mg} / \mathrm{kg} \\
\text { with increase } \\
\text { over } 8 \text { months } \\
\text { to } 2500 \mathrm{mg} / \mathrm{kg} \\
\text { weekly; } 83 \\
\text { months }\end{array}$ & $\begin{array}{l}16 \\
\text { months }\end{array}$ & $\begin{array}{l}\text { IT advanced from } 175 \text { to } \\
875 \text { mg Q15 days; now } \\
\text { receives } 10100 \text { mg } \\
\text { every } 15 \text { days; } 67 \\
\text { months }\end{array}$ & $\begin{array}{l}\text { Port-a-Cath } \\
\text { infection } \\
\text { (twice), } \\
\text { removal after } \\
\text { 2nd infection }\end{array}$ & None \\
\hline SEQ5 & 13 years & $\begin{array}{l}\text { Dysarthria, dysphagia, } \\
\text { partial complex seizures, } \\
\text { worsening ataxia and } \\
\text { VSGP, obstructive sleep } \\
\text { apnea }\end{array}$ & $\begin{array}{l}500 \mathrm{mg} / \mathrm{kg} \\
\text { advanced to } \\
2000 \mathrm{mg} / \mathrm{kg} \\
\text { twice weekly; } \\
72 \text { months }\end{array}$ & $\begin{array}{l}13 \\
\text { months }\end{array}$ & $\begin{array}{l}350 \text { mg Q2 weeks, } \\
\text { advanced to } 600 \text { mg Q2 } \\
\text { weeks, then dropped to } \\
500 \text { mgQ2 weeks; } 59 \\
\text { months ' } L P\end{array}$ & None & $\begin{array}{l}\text { Nausea, emesis thought } \\
\text { secondary to } \\
\text { dehydration; Increased } \\
\text { frequency seizures for } \\
24 \text { h post IT; Mild high } \\
\text { frequency hearing loss } \\
\text { at } 500-600 \mathrm{mg}\end{array}$ \\
\hline SEQ6 & 10 years & $\begin{array}{l}\text { Splenomegaly, mild } \\
\text { VSGP; precocious } \\
\text { puberty (not related to } \\
\text { NPC) }\end{array}$ & $\begin{array}{l}500 \mathrm{mg} / \mathrm{kg} \\
\text { advanced to } \\
2000 \mathrm{mg} / \mathrm{kg} \\
\text { twice weekly; } \\
68 \text { months }\end{array}$ & $\begin{array}{l}10 \\
\text { months }\end{array}$ & $\begin{array}{l}350 \text { mg Q2 weeks, } \\
\text { advanced to } 500 \text { mg Q2 } \\
\text { weeks; } 59 \text { months }\end{array}$ & None & $\begin{array}{l}\text { Mild high frequency } \\
\text { hearing loss at } 500 \mathrm{mg}\end{array}$ \\
\hline SEQ7 & 2 years & $\begin{array}{l}\text { Progressive } \\
\text { neurocognitive decline, } \\
\text { VSGP, lung disease, } \\
\text { thrombocytopenia, } \\
\text { leukopenia }\end{array}$ & $\begin{array}{l}1500 \mathrm{mg} / \mathrm{kg} \\
\text { weekly to } \\
2000 \mathrm{mg} / \mathrm{kg} \\
\text { weekly; } 58 \\
\text { months }\end{array}$ & $\begin{array}{l}23 \\
\text { months }\end{array}$ & $\begin{array}{l}150 \text { mg every } 2 \text { weeks, } \\
\text { dose escalation to } 750 \\
\text { mg every } 2 \text { weeks; } 35 \\
\text { months }\end{array}$ & $\begin{array}{l}\text { Pneumonia, } \\
\text { viral illnesses }\end{array}$ & None reported \\
\hline SEQ8 & $\begin{array}{l}21 \\
\text { months }\end{array}$ & $\begin{array}{l}\text { Worsened } \\
\text { hepatosplenomegaly, } \\
\text { severe growth } \\
\text { retardation, } \\
\text { tracheomalacia/ } \\
\text { bronchomalacia (not } \\
\text { related to NPC), } \\
\text { tracheostomy, ventilator } \\
\text { assist }\end{array}$ & $\begin{array}{l}500 \mathrm{mg} / \mathrm{kg} \\
\text { weekly, } \\
\text { escalated by } \\
500 \mathrm{mg} / \mathrm{kg} \\
\text { monthly to } \\
2000 \mathrm{mg} / \mathrm{kg} \\
\text { weekly; } 30 \\
\text { months }\end{array}$ & 4 months & $\begin{array}{l}175 \text { mg every } 4 \text { weeks; } \\
\text { dose escalated to } 400 \\
\text { mg, then decreased to } \\
300 \text { mg every } 2 \text { weeks; } \\
26 \text { months }\end{array}$ & $\begin{array}{l}\text { CVC } \\
\text { malfunction; } \\
\text { Seizures }\end{array}$ & $\begin{array}{l}\text { Increased seizures } \\
\text { frequency for } 24 \mathrm{~h} \text { post } \\
\text { IT at higher doses ( } 400 \\
\text { mg) }\end{array}$ \\
\hline SEQ9 & 24 years & $\begin{array}{l}\text { Progressive } \\
\text { neurocognitive decline, } \\
\text { memory impairment, } \\
\text { falling, gaze palsy, } \\
\text { swallowing problems }\end{array}$ & $\begin{array}{l}2500 \mathrm{mg} / \mathrm{kg} \\
\text { weekly, } \\
\text { transitioned to } \\
\text { every } 2 \text { weeks; } \\
21 \text { months }\end{array}$ & 1 month & $\begin{array}{l}350 \text { mg every } 2 \text { weeks; } \\
20 \text { months a } L P\end{array}$ & Nausea & Nausea \\
\hline IV1 & 18 years & Spastic quadriplegia, & 500 mg/kg & N/A & N/A & Port-a-Cath & $\mathrm{N} / \mathrm{A}$ \\
\hline
\end{tabular}


Table 1 Clinical manifestations, HPßCD treatment data and adverse events (Continued)

\begin{tabular}{|c|c|c|c|c|c|c|c|}
\hline $\begin{array}{l}\text { Patient } \\
\text { identification }\end{array}$ & $\begin{array}{l}\text { Age at } \\
\text { start of IV } \\
\text { HPßCD } \\
\text { treatment }\end{array}$ & $\begin{array}{l}\text { Symptom progression } \\
\text { at start of IV treatment }\end{array}$ & $\begin{array}{l}\text { Intravenous } \\
\text { treatment } \\
\text { Dose/Interval; } \\
\text { Length of } \\
\text { treatment }\end{array}$ & $\begin{array}{l}\text { Time } \\
\text { interval } \\
\text { between } \\
\text { start of IV } \\
\text { and IT } \\
\text { HPßCD } \\
\text { treatment }\end{array}$ & $\begin{array}{l}\text { Intrathecal treatment } \\
\text { Dose/Interval; Length of } \\
\text { treatment }\end{array}$ & $\begin{array}{l}\text { Adverse } \\
\text { effects, IV } \\
\text { HPßCD }\end{array}$ & $\begin{array}{l}\text { Adverse effects, IT } \\
\text { HP } \beta C D\end{array}$ \\
\hline & & $\begin{array}{l}\text { recurrent pneumonia } \\
\text { (tracheostomy, } \\
\text { ventilator dependent), } \\
\text { dysphagia and enterally } \\
\text { fed, refractory seizure } \\
\text { disorder }\end{array}$ & $\begin{array}{l}\text { weekly, } \\
\text { escalated by } \\
500 \mathrm{mg} / \mathrm{kg} \\
\text { monthly to } \\
2000 \mathrm{mg} / \mathrm{kg} \\
\text { weekly; } 17 \\
\text { months }\end{array}$ & & & $\begin{array}{l}\text { infection; } \\
\text { proteinuria, } \\
\text { elevated } \\
\text { transaminases } \\
5 x \text { baseline; } \\
\text { fevers, } \\
\text { hypertension }\end{array}$ & \\
\hline IV2 & 27 years & $\begin{array}{l}\text { Hepatosplenomegaly, } \\
\text { mild thrombocytopenia, } \\
\text { severe neurocognitive } \\
\text { impairment, wheelchair } \\
\text { dependent, VSGP, } \\
\text { nasogastric tube fed, } \\
\text { severe dysmetria, } \\
\text { seizures }\end{array}$ & $\begin{array}{l}1700 \mathrm{mg} / \mathrm{kg} \\
\text { weekly; } \\
\text { unknown total } \\
\text { length of } \\
\text { treatment; } \\
\text { report of } 26 \\
\text { months for } \\
\text { safety data }\end{array}$ & N/A & N/A & $\begin{array}{l}\text { Pneumonia, } \\
\text { sinus infection, } \\
\text { rash with } \\
\text { infusion }\end{array}$ & N/A \\
\hline IV3 & 25 years & $\begin{array}{l}\text { Schizophrenia type } \\
\text { behavior, gaze palsy, } \\
\text { dysarthria, dysphagia, } \\
\text { hepatosplenomegaly, } \\
\text { thrombocytopenia }\end{array}$ & $\begin{array}{l}2600 \mathrm{mg} / \mathrm{kg} \\
\text { weekly; } \\
\text { unknown total } \\
\text { length of } \\
\text { treatment; } \\
\text { report of } 32 \\
\text { months for } \\
\text { safety data }\end{array}$ & N/A & N/A & $\begin{array}{l}\text { Tremors, chills, } \\
\text { emesis, fever } \\
\text { or headache } \\
\text { during infusion } \\
\text { (3 occasions) }\end{array}$ & N/A \\
\hline
\end{tabular}

SEQ1-9: patients received intravenous followed by addition of intrathecal treatment, IV1-3: patients received intravenous treatment only

$I V$ intravenous, IT intrathecal, IO Intra-Ommaya, VSGP vertical supranuclear gaze palsy, CVC central venous catheter (Port-a-Cath), N/A not applicable

${ }^{a} \mathrm{LP}$ : lumbar port placed for ease of administration and to eliminate sedation

was validated for utilization in both a prospective and retrospective manner [46]. This tool utilizes nine major and 8 minor domains of clinical manifestations. These major domains include: gross motor, fine motor, hearing based on pure tone average, speech, cognition, memory, eye movements, seizures and swallow. The minor domains include: cataplexy, behavior, psychiatric symptoms, hyperreflexia, narcolepsy, continence, auditory brainstem response, and pneumonia. Each major domain is scored from 0 (no evidence) to 5 (severe manifestation); minor domains scored 0 to 2 , and the maximum sum of the scores is 61. Higher scores correlate with more severe clinical signs and symptoms of NPC.

These tools provide practitioners a means for objective measurements and assessments of single clinical manifestations and do not require specialized testing (other than hearing). There can be a fair amount of inter-rater variability and the utility of these tools may rely heavily on methodology (written interpretation guidelines, videography) to limit this variability. All investigators reported in this paper utilized this scale to assess clinical status over time. For patients treated prior to the publication of this tool, the lead author $(\mathrm{CH})$ reviewed medical records available and retrospectively calculated the scores for this publication and correlated scores for verification of data and consistency of reporting, in an effort to decrease inter-rater variability by adding another review. The majority of the scores were confirmed and only minor changes for interpatient consistency were adjusted in the final scores. Given the heterogeneity of clinical disease expression in this case series, as well as concerns for inter-rater variability, the specific assessments used in scoring were patient consistent so that each patient could serve as his/her own control.

All clinical protocols included safety assessments for monitoring of potential adverse reactions during and following drug administration based on the initial 2008 clinical protocol. Assessments included: periodic complete history and physical examinations, hearing evaluations (behavioral audiologic evaluations with calculations of pure tone averages at variable frequencies, tympanography, and, if clinically indicated, auditory brainstem response), laboratory studies (complete blood counts, chemistries, lipid panels, coagulation profiles, urinalyses), neurologic examinations (optional neuroimaging MRI and/or PET, EEG), neurocognitive and eye evaluations. The frequency of such testing was at the discretion of the investigator and institution as well as country or state review boards, though in most cases was temporally related to the treatments and intervals increased over time following months to years of 
safe administration. Adverse events (including severe adverse events, SAEs) were reported to local authorities and appropriate pharmaceutical companies, and the data also captured for this report.

\section{Results}

\section{Demographics}

The demographics, diagnostic studies and initial clinical presentation characteristics of the 12 patients included in this analysis are shown in Table 2. A narrative case history on each patient is provided in a Supplemental report (Additional file 1). Here we provide an overview of the patients, key disease features and details of treatment and outcomes with exposure to HP $\beta C D$.

We collected data from 8 investigators treating 12 patients with NPC. Nine of the 12 patients are female and three are male, and there are three sets of siblings including a pair of identical twins. Seven patients are Caucasian, 4 white Brazilian and 1 Asian. The mean age at diagnosis was 7.5 years with a range of 8 months to

Table 2 Patient characteristics and diagnostic studies, baseline

\begin{tabular}{|c|c|c|c|c|c|}
\hline $\begin{array}{l}\text { Patient } \\
\text { identification }\end{array}$ & Gender & $\begin{array}{l}\text { Age at } \\
\text { diagnosis }\end{array}$ & Signs/Symptoms at diagnosis & Diagnostic tests NPC1 filipin/Genotype & $\begin{array}{l}\text { Miglustat } \\
\text { treatment }\end{array}$ \\
\hline SEQ1 & Female & 3 years & $\begin{array}{l}\text { Splenomegaly, pancytopenia, } \\
\text { cognitive impairment }\end{array}$ & $\begin{array}{l}\text { Cultured fibroblast, positive filipin; } \\
\text { genotype heterozygous for c.1920delG } \\
\text { exon } 12 \text { and IVS9 c.1554-1009G > A missense } \\
\text { mutation }\end{array}$ & yes \\
\hline SEQ2 & Female & 3 years & $\begin{array}{l}\text { Splenomegaly, pancytopenia, } \\
\text { cognitive impairment }\end{array}$ & $\begin{array}{l}\text { Cultured fibroblast, positive filipin; } \\
\text { genotype heterozygous for c.1920delG } \\
\text { exon } 12 \text { and IVS9 c.1554-1009G > A missense } \\
\text { mutation }\end{array}$ & yes \\
\hline SEQ3 & Female & 7 years & Cognitive impairment & $\begin{array}{l}\text { Cultured fibroblast, equivocal filipin; } \\
\text { genotype heterozygous for c.1552C > } \\
\text { T, p.R518W (p.ARG518Trp) in exon } 9 \\
\text { and c.2594C > T, p.5865 L (p.Ser865Leu) } \\
\text { in exon } 17\end{array}$ & yes \\
\hline SEQ4 & Female & 5 years & Ataxia & $\begin{array}{l}\text { Cultured fibroblast, equivocal filipin; genotype } \\
\text { heterozygous for c.1552C > T, p.R518W } \\
\text { (p.ARG518Trp) in exon } 9 \text { and c.2594C > } \\
\text { T, p.5865 L (p.Ser865Leu) in exon } 17\end{array}$ & yes \\
\hline SEQ5 & Male & 10 years & $\begin{array}{l}\text { Dysarthria, cognitive impairment, } \\
\text { anxiety, hypotonia, VSGP }\end{array}$ & $\begin{array}{l}\text { Cultured fibroblast, positive filipin; } \\
\text { genotype heterozygous for R978C } \\
\text { missense and IVS21-2 A > G splice } \\
\text { site mutation }\end{array}$ & yes \\
\hline SEQ6 & Female & 7 years & Splenomegaly, VSGP & $\begin{array}{l}\text { Cultured fibroblast, positive filipin; } \\
\text { genotype heterozygous for R978C } \\
\text { missense and IVS21-2 A > G splice } \\
\text { site mutation }\end{array}$ & Yes \\
\hline SEQ7 & Male & 2 years & $\begin{array}{l}\text { Neonatal hepatosplenomegaly, } \\
\text { conjugated hyperbilirubinemia, } \\
\text { hypotonia, global developmental } \\
\text { delay, failure to thrive }\end{array}$ & $\begin{array}{l}\text { Cultured fibroblast, positive filipin; } \\
\text { Genotype heterozygous for c.2008_- } \\
\text { 2011delITGCT and c.3565_3566insG }\end{array}$ & yes \\
\hline SEQ8 & Female & 1 year & $\begin{array}{l}\text { Liver dysfunction, cholestatic } \\
\text { jaundice, hepatosplenomegaly, } \\
\text { developmental delay }\end{array}$ & $\begin{array}{l}\text { Genotype heterozygous for c.2213C > } \\
\text { A and c.3234_3237dupATTा }\end{array}$ & Yes \\
\hline SEQ9 & Female & 20 years & $\begin{array}{l}\text { Cognitive decline, ataxia, } \\
\text { hepatosplenomegaly }\end{array}$ & $\begin{array}{l}\text { Cultured fibroblast, positive filipin; } \\
\text { Genotype heterozygous for c.688_ } \\
\text { 69delTCTGTG and c.3182 T>C }\end{array}$ & No \\
\hline IV1 & Female & 8 months & $\begin{array}{l}\text { Hepatosplenomegaly, liver } \\
\text { fibrosis, difficulty feeding }\end{array}$ & $\begin{array}{l}\text { Cultured fibroblast, positive filipin; } \\
\text { Genotype heterozygous for p.1923V } \\
\text { and A1151T (c.2767A }>\text { G/3541G > A) }\end{array}$ & No \\
\hline IV2 & Male & 15 years & $\begin{array}{l}\text { Hepatosplenomegaly, } \\
\text { behavioral disturbance, } \\
\text { epilepsy, cognitive decline }\end{array}$ & $\begin{array}{l}\text { LS-509 biomarker normal; Confirmed } \\
\text { NPC1 gene mutation, results not } \\
\text { available }\end{array}$ & yes \\
\hline IV3 & Female & 16 years & $\begin{array}{l}\text { Liver dysfunction at birth, } \\
\text { hepatosplenomegaly, } \\
\text { schizophrenia }\end{array}$ & $\begin{array}{l}\text { LS-509 biomarker increased; genotype not } \\
\text { available }\end{array}$ & yes \\
\hline
\end{tabular}


20 years. The mean age of initiation of treatment was 13 years (range 21 months to 27 years) with a mean interval from diagnosis to treatment of approximately 5.5 years. The majority of patients (10 of 12) received miglustat prior to treatment and continued on the medication while receiving $\mathrm{HP} \beta C D$. The data on length of treatment or patient compliance with miglustat are not available. At the time of intervention with $\mathrm{HP} \beta C D$, miglustat was considered to be part of a standard of care regimen and the only published disease altering therapy.

Limited data are available for two patients (IV2 and IV3) with respect to duration of therapy (26 and 32 months, respectively) but are included here for contribution to the safety data. Both of these patients received Trappsol $^{\ominus}$ Cyclo $^{\mathrm{Tm}}$ exclusively. Nine patients received Trappsol $^{\odot} \mathrm{Cyclo}^{\mathrm{Ts}}$, four exclusively (two for 83 months each). The five patients that transitioned HP $\beta C D$ products (SEQ1, 2, 5, 6, 7) received Trappsol $^{\oplus} \mathrm{Cyclo}^{\mathrm{TM}}$ an average of 36 months, with a range of 11 to 52 months prior to the switch to the alternate $\mathrm{HP} \beta C D$. Of the 9 patients receiving IV (including SEQ3 and SEQ4 exclusive use) the average duration of exposure to Trappsol $^{\circledR} \mathrm{Cyclo}^{\text {тм }}$ was 44.8 months (range 11 to 83 months). In total, patients received $\mathrm{HP} \beta C D$ an average of 56.2 months (range 17 to 92). Patient exposure is therefore heavily weighted (80\%) towards $\mathrm{Trappsol}^{\circ} \mathrm{Cyclo}^{\mathrm{TM}}$ in this group of patients. Patients received one or both $\mathrm{HP} \beta C D$ products but this report will not separate the clinical and safety outcomes by products and no data is available suggesting benefit of one over the other. For those patients who were exposed to both products, there was no change in status or adverse effects that could be attributed to change in formulation in careful review of the data.

Further details about the patients' disease severity at initiation of treatment, treatment pathway (route, dose and interval), and adverse effects of treatment are provided in Table 1. All 12 patients received IV HP $\beta C D$. Nine of the 12 patients received IV treatment followed by the addition of IT sequentially (SEQ1-9). Three of the 12 patients received IV treatment exclusively (IV1-3). Decisions regarding IV and/or IT dosing, intervals and route of therapy were at the discretion of the investigator and patient family. For the ten patients with interval data, the duration of time patients received IV therapy ranged from 17 to 92 months and the average time of IV alone prior to IT for the sequential patients was 13 months (range 1 to 23 months).

The range of phenotypic expression of the disease (Table 2) ranged from relatively asymptomatic, juvenile onset (patient SEQ6 with a history of splenomegaly, mild VSGP and hyperreflexia) to severely affected early onset (IV1 and IV2, both with severe cognitive impairment, immobility, loss of language, and decreased ability to swallow and protect the airway). Nine patients had initial diagnostic testing utilizing cultured skin fibroblast for filipin staining ( 2 of whom had equivocal results) and 11 of 12 patients had genetic confirmation of NPC1 and displayed an array of mutations as has been reported with this disease [11, 24, 68]. One patient's diagnosis was based on results of the LS-509 testing and clinical features of the disease [69-71].

Most patients had surgical placement of central venous catheters to allow safer and more efficient delivery of the IV formulation. Nine patients received IT therapy and an additional 3 patients had Ommaya reservoirs placed for IO therapy. Two adolescent/young adult patients had lumbar ports place for ease of administration and avoidance of sedation (SEQ5 and SEQ9).

\section{Safety and adverse events}

Adverse events are summarized in Table 1. SAEs requiring immediate reporting included a post-operative hemorrhage following placement of the Ommaya reservoir in patient SEQ2 as well as Port-a-Cath infections (SEQ3, SEQ4, IV1) and an Ommaya infection/meningitis (SEQ3). These SAEs were attributed to protocol devices and not to the drug. Two Port-a-Caths and two Ommaya reservoirs were removed due to these events; another Port-a-Cath required revision due to device malfunction. Two patients continue to have a long-standing Ommaya reservoir/catheter system (SEQ1, SEQ4).

The most common AEs were grade 1 and 2, requiring either no intervention or supportive measures alone, and included: infusion reactions with nausea (IV, IT) or headache (IT) and increased seizure activity for up to 24 $\mathrm{h}$ following IT (or IO) treatment. Increased seizure activity occurred in patients with a prior history of seizure activity (SEQ1, SEQ2, SEQ5, SEQ8). Patients SEQ3 and SEQ4 experienced transient worsening of ataxia, dysarthria and worsened fine motor control following high (1000 mg) intra-Ommaya (IO) doses which did not occur at lower (100-350 mg) doses. Patient SEQ5 experienced increased lethargy and ataxia for 1 week following IT administration at $600 \mathrm{mg}$, but no adverse events with a $500 \mathrm{mg}$ dose. Patients also experienced periodic viral infections, otitis, sinusitis, diarrhea, and pneumonias not attributable to drug or disease. No patient experienced hearing loss as a result of IV therapy though two patients reported mild hearing loss in high frequencies with IT treatment (SEQ5, SEQ6). No patient discontinued the medication due to an adverse reaction.

A review of laboratory assessments (complete blood counts, chemistries, lipid panels, coagulation studies and urinalyses) do not show any trend or new abnormalities amongst the patients. Some patients had pre-treatment leukopenia, thrombocytopenia or anemia attributed to hypersplenism, which was noted to worsen transiently with viral infections (SEQ1, SEQ2). Most patients showed mild pre-treatment elevations of liver transaminases, with 
the exception of those with a history of cholestasis (SEQ7, SEQ8) in which the elevations were marked.

\section{Clinical severity scores and assessments}

A number of patients had frequent assessments, but for consistency we have reported NPC Clinical Severity Scores (NCSS) at approximate 6-month intervals in this report (Fig. 1). The baseline scores prior to initiation of IV and IT are included, and, for patients with available medical records, retrospective scores have also been calculated to establish rate of disease progression. Each patient serves as their own control for comparison of severity scoring.

We performed a comparison of regression lines for patients with at least 3 data points (clinical severity scores) pre-and post-IV infusion of $\mathrm{HP} \beta C D$ with comparison of slopes and intercepts. $P$-values were calculated for overall test of coincidence. Table 3.

This is a descriptive study of compassionate use protocols (adapted for the individual patients in some circumstances) and therefore no power calculations were performed. The rate of change between the pre- and post-infusion time points, as calculated by the slope of the line between scores, proved statistically significant for patients SEQ1 and SEQ2, as well as patients SEQ3 and SEQ4. The $p$-values did not suggest relevance for patients SEQ5 and SEQ6. These values were calculated as related to time of initiation of IV infusion. Though nine patients sequentially received IT therapy there were not enough time points to create 2 sets of posttreatment lines (with calculated slopes) to determine if statistically significant changes occurred with the sequential addition of IT therapy. Observation of the slopes in Fig. 1 suggests the patients did not show added benefit (as measured by a decrease in the clinical severity score) when IT (or IO) therapy was added to the treatment regimen. How CNS directed therapy (in SEQ patients) contributed to disease stability is not possible to determine.

Patients presenting with severe clinical manifestations (typically with NCSS over 30) demonstrate progression of disease with increasing scores over time and then appear to plateau (no change in scores). Patients with an apparent plateau may still show periodic declines but not to a degree that will alter the NCSS, and this adds another element of complexity in the interpretation of results. It is unknown if our findings may represent natural history of disease progression or is an effect of intervention. Two less severely affected patients had immediate and notable decreases in their scores (SEQ3, SEQ4) with initiation of IV therapy, and though some progression was seen years later, these patients never reached the pre-infusion level of clinical severity scores. The change in scores, as well as the reports from the investigators and patient families (not all observed changes are quantified with the NCSS), indicate improvement in clinical symptoms of disease. Of interest, patient SEQ6 presented relatively asymptomatic and has remained so for the duration of the treatment. Given the patient's stability, it is not possible to determine the natural history for this patient versus a changed course due to this intervention.

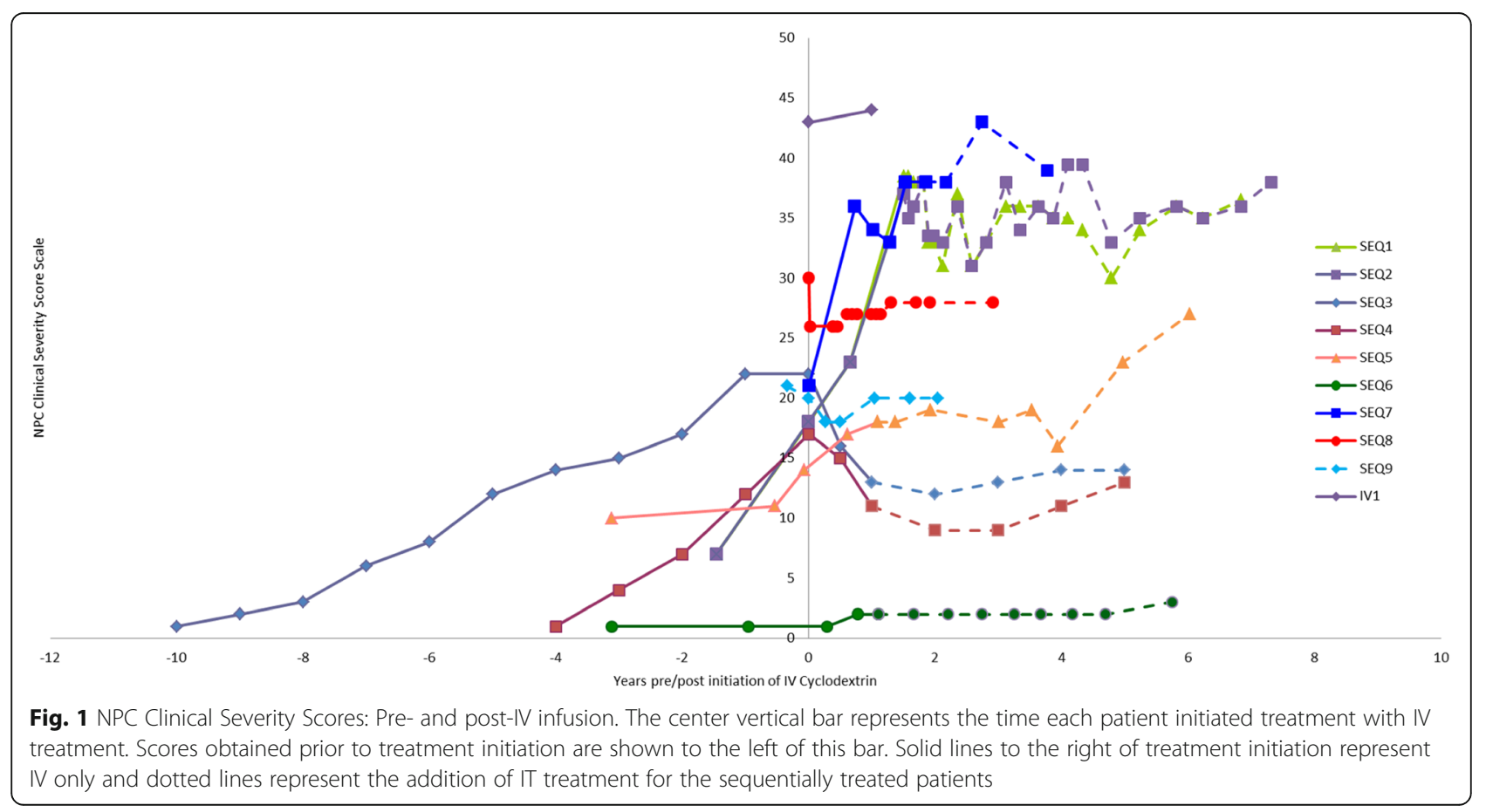


Table 3 Overall test of coincidence of regression lines

\begin{tabular}{llll}
\hline Patient ID & Slope pre-IV & Slope post-IV & $p$-value \\
\hline SEQ1 & 7.55 & 0.96 & $<0.001$ \\
SEQ2 & 7.55 & 0.72 & $<0.001$ \\
SEQ3 & 2.32 & -0.97 & $<0.001$ \\
SEQ4 & 3.60 & -0.75 & 0.015 \\
SEQ5 & 1.00 & 1.39 & 0.616 \\
SEQ6 & 0 & 0.18 & 0.236 \\
SEQ7 & N/A & 4.19 & $\mathrm{n} / \mathrm{a}$ \\
SEQ8 & N/A & 0.37 & $\mathrm{n} / \mathrm{a}$ \\
SEQ9 & N/A & 1.29 & $\mathrm{n} / \mathrm{a}$ \\
IV1 & N/A & 1 & $\mathrm{n} / \mathrm{a}$
\end{tabular}

Slopes were calculated independently for pre-intravenous (pre-IV) infusions and post-IV infusions, and when data was available for both, $p$-values were generated

N/A data not available, $n / a$ not applicable

A surprising finding was improvement in some of the neurologic (fine and gross motor, swallowing), neurocognitive and/or behavioral and psychiatric manifestations of the disease in two patients (SEQ3 and SEQ4). Additionally, one patient with lung disease (SEQ7) (Fig. 2 CT scans for Patient SEQ7 prior to (A) and after 9 months of treatment (B) with IV HP $\beta C D$ ) and another with massive hepatomegaly and elevated AST (SEQ8) (Table 4) showed clinical improvements related in time to initiation of IV (and prior to IT) treatment. The beneficial effect of $H P \beta C D$ on lung disease in one of our patients (SEQ7) is an interesting observation considering that the results of in vivo studies showed that treatment with $\mathrm{HP} \beta C D$ had a minimal effect on lung cholesterol and collagen levels in an NPC mouse model and caused pulmonary toxicity in an NPC cat model $[60,73]$. The differences in these results may be due to influence of parenchymal disease or the production of specific lung secretions, or be species specific.

Patients less severely affected appeared to benefit more with improvements or stability than those more severely affected, and not all these improvements related to quality of life were captured in the NCSS. Another interesting observation was that the addition of IT therapy (or IO) did not result in additional improvement in symptoms.

Review of the medical records note a number of patients experienced increased well-being attributable to increased ability to focus or increased alertness resulting in improved communication, less confusion, improved behavior and better ability to manage activities of daily living. These changes were reported by the parents as well as treating physicians for patients SEQ1, SEQ2, SEQ3, SEQ4, SEQ5, SEQ6, SEQ7 and SEQ9. As this was not part of the clinical severity score or protocol, this information on general well-being or quality of life (utilizing validated tools) was not sought and is anecdotal, but we note these comments in the medical records here to be of interest. Formal quality of life assessments should be addressed in future clinical trials.

\section{Discussion}

In this case study analysis, we report on the safety and clinical observations following the administration of $\mathrm{HP} \beta C D$ in 12 patients with NPC (11 genetically confirmed NPC1). These cases include patients who have received long durations of IV treatment with HP $\beta C D$ (range 17 to 92 months) and highlight important safety and efficacy data following long-term use. We did not encounter any serious adverse event (SAE) in the administration of IV
A

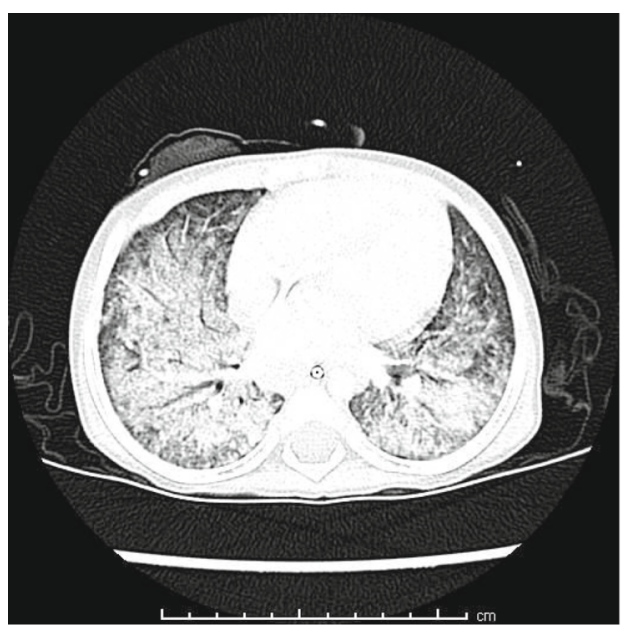

CT, computed tomography; IV, intravenous
B

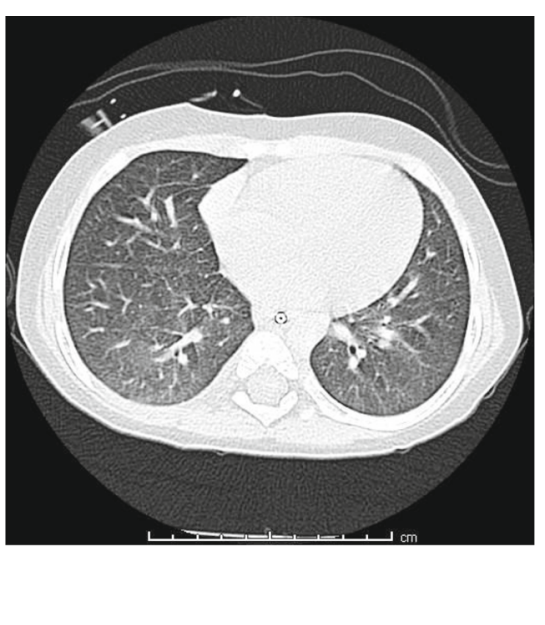

Fig. 2 CT scans for Patient SEQ7 prior to (a) and after 9 months of treatment (b) with IV HP $\beta C D$. CT, computed tomography; IV, intravenous 
Table 4 Change in liver volume and liver enzymes in patient SEQ8

\begin{tabular}{|c|c|c|c|c|c|c|c|c|}
\hline $\begin{array}{l}\text { Age at Liver } \\
\text { MRI }\end{array}$ & $\begin{array}{l}\text { Treatment IV, } \\
\text { IT HPBCD }\end{array}$ & $\begin{array}{l}\text { Liver } \\
\text { volume } \\
\left(\mathrm{cm}^{3}\right)\end{array}$ & $\begin{array}{l}\text { Liver volume/ body } \\
\text { weight }\left(\mathrm{cm}^{3} / \mathrm{kg}\right)\end{array}$ & $\begin{array}{l}\text { Normal range liver volume/ } \\
\text { body weight }\left(\mathrm{cm}^{3} / \mathrm{kg}\right)[72]\end{array}$ & $\begin{array}{l}\text { AST (U/L) } \\
\text { RR 15-46 }\end{array}$ & $\begin{array}{l}\text { ALT (U/L) } \\
\text { RR 3-35 }\end{array}$ & $\begin{array}{l}\text { GGT (U/L) } \\
\text { RR 5-55 }\end{array}$ & $\begin{array}{l}\text { AP }(U / L) \\
\text { RR } 80-270\end{array}$ \\
\hline $\begin{array}{l}1 \text { year } 9 \\
\text { months, } \\
\text { Baseline }\end{array}$ & Pre-IV & 772 & 91.4 & $28.56+/-5.4$ (1 year, 6 months) & 88 & 37 & 116 & 274 \\
\hline $\begin{array}{l}2 \text { years } 2 \\
\text { months }\end{array}$ & $\begin{array}{l}\text { Continued IV, } \\
\text { pre-IT }\end{array}$ & 767 & 71.1 & $\begin{array}{l}31.83+/-5.9 \text { ( } 3 \text { years } 4 \\
\text { months) }\end{array}$ & 75 & 28 & 102 & 189 \\
\hline $\begin{array}{l}2 \text { years } 9 \\
\text { months }\end{array}$ & IV/IT & 699 & 58.5 & $\begin{array}{l}31.83+/-5.9 \text { ( } 3 \text { years } 4 \\
\text { months) }\end{array}$ & 41 & 28 & 77 & 171 \\
\hline $\begin{array}{l}3 \text { years } 9 \\
\text { months }\end{array}$ & IV/IT & 777 & 49.8 & $\begin{array}{l}31.83+/-5.9 \text { ( } 3 \text { years } 4 \\
\text { months) }\end{array}$ & 40 & 36 & $<10$ & 159 \\
\hline $\begin{array}{l}4 \text { years } 11 \\
\text { months }\end{array}$ & IV/IT & 812 & 47.5 & $\begin{array}{l}31.83+/-5.9 \text { ( } 3 \text { years } 4 \\
\text { months) }\end{array}$ & 41 & 37 & 113 & 169 \\
\hline
\end{tabular}

Absolute volumetric liver measurements are shown with respect to age and timing of either IV, or sequential IV + IT treatment. A marked decrease in liver size relative to weight and expected volume by age [72] is seen following initiation of IV treatment and continues to decrease with sequential treatment. Liver enzymes show variability at baseline though AST decreases from twice upper limit of normal to a normal range to normal following 1 year of treatment $M R I$ magnetic resonance imaging, IV intravenous, IT intrathecal, AST aspartate aminotransferase, ALT alanine aminotransferase, GGT gamma-glutamyl transpeptidase, $A P$ alkaline phosphatase, $U / L$ units per liter, $R R$ reference range

$\mathrm{HP} \beta C D$. Some patients experienced mild infusion reactions, which were subsequently prevented with use of anti-emetic pre-medication or assuring adequate hydration. The patients were able to transition to receive home IV infusions given the ease and safety of administration.

\section{Impact of intravenous $\mathrm{HP} \beta C D$ on clinical course}

The efficacy data arising from our case series suggest clinical improvements in the systemic and neurologic manifestations of NPC disease following the IV administration of $\mathrm{HP} \beta C D$. It is emphasized that this is a case series and not a powered study, confounded by patient heterogeneity and variability in interventions. We report here our observations suggesting a clear safety profile as well as potential benefit, that support the need for formal clinical trials. The observed improvements include reduced hepatomegaly, improved transaminase levels, improved fine and gross motor control, improved behavior with amelioration of psychiatric symptoms, and the resolution of interstitial lung disease (in one affected patient). The improvements in measurable neurocognitive function in some patients, as well as the unsolicited reports of increased alertness and focus in even the most severely affected patients, conflict with our prior notion that $\mathrm{HP} \beta C D$ does not cross the blood brain barrier (BBB) and would therefore not be expected to affect clinically apparent change [74]. However, we cannot exclude the possibility that $\mathrm{HP} \beta C D$ is crossing in low concentrations sufficient for response or is acting at the level of the $\mathrm{BBB}$ regulating brain cholesterol metabolism, by means of signaling or changes in paracellular permeability or tight intercellular junctions, altering membrane structures, or by influencing solubilization of lipids of brain endothelial cells [75-79]. Cyclodextrins directly interfere with biological membranes, without penetration, to extract lipids such as cholesterol and are known to influence cell metabolism and function [76].

Interestingly, many of the patient families and healthcare providers in this case series anecdotally reported observations including an increase in level of patient alertness, ability to communicate and general well-being leading to improved quality of life following initiation of IV infusions, clinical assessments not captured in the NCSS tool. These changes would indicate that additional measures in quality of life would be beneficial to include in future trials. Additionally, measures of change in systemic manifestations of disease need to be developed to address a sub-population of patients, as these areas are not specifically measured in the NCSS.

The benefits observed in these cases were reported early in the patients' treatment pathway (often within several doses) and were sustained throughout the duration of the IV HP $\beta C D$ treatment. It would not be possible to determine an added effect of each agent (including prior miglustat treatment) in the long-term disease progression, though a number of non-neurologic as well as immediate changes noted with initiation of $\mathrm{HP} \beta C D$ suggests a true benefit of this latter agent. Given that miglustat is currently the only published disease altering treatment, future clinical trials with other agents will need to address the same issue.

Furthermore, we did not observe new or immediate changes or improvements amongst the cases in which IT therapy was subsequently added to IV treatment. Of note, $75 \%$ of the patients added IT administration to IV administration within 1-2 years of initiating IV therapy. Patients who were less severely affected at initiation of IV treatment experienced more benefit than those with severe manifestations, and likely this is due to the degree 
of irreversible damage present in some patients. A number of the patients in this case series were severely compromised at the time of treatment initiation and indeed this may have precluded the possibility of clinical benefit. Prior preclinical studies in mouse and feline NPC models demonstrated that young animals responded more favorably and older animals showed lesser benefits, again supporting the notion that age and severity are important factors with respect to response (or possible benefit) to treatment $[53,55,60,80]$. The majority of patients remained clinically stable and no additional improvements were noted with the addition of IT therapy (with the exception of the identical twin patients SEQ1 and SEQ2 who experienced an improvement in hearing on a stable low dose meeting certain concentration goals as measured on pharmacokinetic sampling and modeling). It is not possible to determine if disease stability or slowing of progression is related to IV and CNS directed therapy, or an additive effect of miglustat and HP $B C D$. Improvements in systemic manifestations (liver, lung) could not be explained by miglustat treatment.

\section{Safety assessment and adverse events}

The safety data obtained in this analysis showed that several AEs were reported following the administration of $\mathrm{HP} \beta C D$. However, some of these adverse events were consistent with the natural history of NPC. In total, we believe that two notable safety findings were reported in these case studies, namely systemic reactions to the IV administration of HP $\beta C D$ and AEs associated with implanted devices designed to facilitate long-term parenteral or CNS directed administration. The increased seizure activity observed in some patients receiving IT $\mathrm{HP} \beta C D$ (with a known prior history of seizure activity) is presumably due to a transiently lowered seizure threshold, though the mechanism is unknown. Data was not collected to specifically evaluate this relationship with dosing, frequency, route (IO/IT) or other factors which may affect neurologic irritability. Additionally, as measured by behavioral audiologic and ABR testing, high frequency hearing loss was reported in some patients following IT therapy, as has been previously reported in the NIH clinical trial, but not in the patients receiving IV therapy [81]. The systemic reactions that were noted did not lead to treatment discontinuation and are not unusual with IV infusion of a therapeutic agent. These reactions were readily managed with conventional clinical practice and specific measures could be initiated to limit their occurrence in the future. Given the progressive, degenerative nature of NPC, it may be difficult to distinguish safety related treatment adverse events from those related to disease progression. Nevertheless, based on the safety data we report here, we consider that no unexpected safety issues were experienced.
Initial case reports have been previously published (utilizing the Hastings/Hempel protocol) of the use of $\mathrm{HP} \beta C D$ to treat patients with NPC. Improvements in hepatosplenomegaly and CNS dysfunction were observed following the administration of IV HP $\beta C D$ to two Japanese patients with NPC [82]. However, no improvements in neurological deficits were observed in that report. Of note, these patients appeared to have been severely neuro-cognitively impaired and such damage was likely already irreversible. The investigators subsequently reported on IT administration of $\mathrm{HP} \beta C D$ in an 8 year old girl with perinatal onset of disease, who remained stable with severe neurologic dysfunction for 2 years [83]. Of note, the authors state the parents observed the patient to become more alert. Furthermore, no adverse effects were observed over the course of treatment. In a subsequent case report, IV $\mathrm{HP} \beta C D$ was administered twice weekly, following the Hastings/Hempel protocol, to a single patient at a dose of $2500 \mathrm{mg} / \mathrm{kg}$ over $8 \mathrm{~h}$ to a 4 year old girl with hepatosplenomegaly and neurocognitive decline [59]. Pharmacokinetic studies were done and comparable effective drug concentrations were achieved which were similar to the in vivo studies in mice reported by Liu et al. $[55,59]$. The authors did not report on clinical outcomes but noted no adverse effects. Two additional case reports of IT HP $\beta C D$ in patients have recently been published [84, 85]. Two adult late onset patients received IT HP $\beta C D$ without improvement or change in progression, and the authors attribute this lack of improvement to be related to age and severity of disease [84]. A recent review of published cases of HP $\beta C D$ treatment for NPC summarized 17 patients, including abstracted data from some of the patients reported in this case study, note the significant toxicities (hearing loss, meningitis) were seen in patients receiving CNS directed drug [86]. Results were suggestive that efficacy may be partial and dependent on multiple factors including severity of disease, timing of drug initiation with respect to disease progression, route and dose of $\mathrm{HP} \beta C D$, and other interpersonal variables.

An emerging area of interest and investigation is the association of NPC with gastrointestinal (GI) symptoms. A recent association of NPC with Crohn's phenotype has been reported [87] as well as ineffective carbohydrate metabolism [88]. These reports point to evidence of systemic disease in some affected individuals with NPC that may experience particular benefit with treatment aimed at affected peripheral organs. A recent study examining impact of a small molecule, ursodeoxycholic acid (UDCA) believed to act by rescuing a suppressed cytochrome P450 system, on liver function in NPC patients showed stabilization or improvement of liver enzymes [34]. This drug was delivered systemically, well tolerated, and appeared to have neurologic benefit based on improvement in clinical severity scores and parent 
reported neurological benefits, including increased alertness, improved sleep patterns, and increase in appetite. More investigation is needed in this area.

\section{Limitations}

This descriptive review of compassionate use data in 12 patients does have limitations by virtue of its nature. Our review is a descriptive analysis and was not designed as a clinical study. We have also provided a historical account of the investigators' process of bringing $\mathrm{HP} \beta C D$ as a potential intervention to patients with NPC. As discussed, we performed a retrospective review of cases, though some of the data was collected prospectively. Some of the clinical NCSS scoring was done post-hoc for patients treated prior to this published tool in 2010 and drew upon a detailed review of the medical records. The patients were not standardized by degree of disease severity, age, length of symptoms, or type of clinical manifestations, as might be controlled in a clinical trial. Patients serving as their own controls in natural history as well as clinical trials in rare disease with such variability of genotypic/phenotypic expression is a means to address some of these issues. Some symptom assessments were subjectively recalled by caregivers potentially biased by an open-label placebo effect. A confounding factor of this case series is that the population of patients is very heterogeneous in terms of age, disease severity, length of symptoms prior to treatment, rate of disease progression, and route (and dosing) of $\mathrm{HP} \beta C D$ administration. Many patients received supplements and other medications (including miglustat) to address underlying consequences of NPC such as seizures, and this could not be controlled for this case series. The data acquired therefore need to be considered on an individual as well as on a collective basis.

The NCSS, a validated tool for clinical assessment in NPC, has limitations in that not all clinical signs or symptoms of NPC are captured. This tool primarily utilizes assessments of neurocognitive and not systemic disease manifestations [46]. Additionally, it may not be reasonable to assume all patients would follow the same trajectory of disease progression, and indeed some patients may seemingly plateau at certain levels though may still have periods of continued decline at variable rates and perceptibility. As well, not all patients may be expected to continue to progress in or reach the most extreme outcome in each domain. It was also noted that in one patient (SEQ5) a tonsillectomy led to notable clinical improvements in swallow and speech, the severity of which had been previously attributed to NPC. Not all changes on the NCSS will be a direct result of disease progression or improvement related to effective treatment. The NCSS was validated in patients ages 4 to 51 years of age, and these assessments are indeed difficult to ascertain in the child younger than 4 years, and the progression may not be so predictable when accounting for variability in developmental milestones. A recently developed tool, denoted annual severity increment score (ASIS), addressed the variability in progression of disease as related to age [89]. This score has promise to serve as a prognostic tool for new treatment interventions.

In this report, we have attempted to determine if expanded access IV HP $\beta C D$ intervened with the projected natural history of disease progression as predicted by the NCSS tool. We applied linear regression modeling for individual patients, whereas the previously reported validation of the NCSS tool averaged the slopes for all patients. Our mathematical modeling suggests that for some of the patients the change in slopes pre-and post-infusion were not coincidental and indeed likely represent an effect of intervention. Our analyzable data is limited by the number of data points available for all patients for both pre- and post-infusion, and true calculations for significance could only be done for those with an adequate number of data points. We compared the trajectory of progression for individual patients based on their preinfusion rate of change (each patient served as his/her own control). Based on the previously reported NCSS validation study, once patients become symptomatic it is anticipated they will continue to have progressive disease as measured by an increasing score over time [46]. However, we could not know with certainty that each patient would indeed follow a specific rate of progression given the variability in severity of disease in our patient population.

Outcome for one of our cases (SEQ6) suggests that IV HP $\beta C D$, when provided to an asymptomatic patient, could have a preventative effect in symptom development. Intervention with $\mathrm{HP} \beta C D$ in asymptomatic animals (mice and cats) prolonged life as well as led to marked delays in disease progression [53, 55, 60, 80]. Based on this patient's low and stable NCSS for the duration of treatment (68 months) we cannot predict with certainty what the disease trajectory would have otherwise been in this patient. The patient's course has differed from that of the sibling, who was initiated on therapy after already developing manifestations of the disease, though it is known siblings may vary in their clinical course [1,90-92]. The patient's clinical stability is nevertheless intriguing and brings up the question of the importance of timing to initiate a potentially effective intervention.

We captured some clinical changes (albeit anecdotally) that impacted quality of life in a positive manner following IV treatment in the medical records and 
with discussion between patients, families and physicians. Given this intriguing finding, it will be critical to include Quality of Life assessments for future clinical trials that will assess such measures as alertness, ability to focus (improved ability to read), specific behavior changes, school and family relationships.

\section{Conclusions}

These case studies demonstrate that IV HP $\beta C D$ is a welltolerated treatment that can potentially treat systemic and neurologic manifestations of disease in patients with NPC1. While progressive decline was expected in accordance with previously published natural history data [24, 46], the rate of progression appears to be less than expected in some individuals receiving IV HP $\beta C D$. Optimal dosing, dosing interval and route that will enhance outcome for patients with NPC are yet to be determined.

A multi-system disease such as NPC requires a multitargeted treatment approach. It is also important to consider the heterogeneity of the disease as an approach in one patient may not be the most appropriate for another. HP $\beta C D$ will certainly play a significant role in targeting the cellular cholesterol burden known to be present in NPC, a mechanism different from that of miglustat which targets sphingosine and glycosphingolipids. Novel agents are urgently needed.

Our series of patients presented here represent the largest collection of patients treated with IV HP $\beta C D$. With demonstration of a favorable safety profile and encouraging clinical outcomes, further validation with a randomized clinical trial is needed. Two formal clinical trials are currently underway to evaluate safety, pharmacokinetic and pharmacodynamic assessments of systemic IV administration of HP $\beta C D$.

\section{Supplementary information}

Supplementary information accompanies this paper at https://doi.org/10. 1186/s13023-019-1207-1.

Additional file 1. Supplemental Data: Case Summaries on

Compassionate Use HP $\beta C D$ to accompany the manuscript "Expanded access with intravenous hydroxypropyl- $\beta$-cyclodextrin to treat children and young adults with Niemann-Pick disease Type C1: A case report analysis". Narratives.

\section{Abbreviations}

AE: Adverse event; BBB: Blood brain barrier; CNS: Central nervous system; CRF: Case report form; FDA: Food and Drug Administration; Gl: Gastrointestinal; HPßCD: Hydroxypropyl- $\beta$-cyclodextrin; IND: Individual New Drug; IO: Intra-Ommaya; IRB: Institutional Review Board; IT: Intrathecal; IV: Intravenous; NCSS: NIH Clinical Severity Scale; NIH: National Institute of Health; NPC: Niemann-Pick disease Type C; SAE: Serious adverse event; SEQ: Sequential, patients treated IV then added IT; VSGP: Vertical supranuclear gaze palsy
}

\section{Acknowledgments}

We are grateful to UnoHealthcare, Florida, for assistance in data collection activities undertaken in Brazil. The authors are grateful for assistance with statistical analysis to Ward Hagar, MD, UCSF Benioff Children's Hospital Oakland, Oakland, CA, USA.

We are grateful for a pre-submission review of an early draft by Dr. Marc Patterson. His insightful comments were helpful as we prepared this manuscript.

We would like to acknowledge Janssen Research \& Development who provided Kleptose ${ }^{\circledast}$ HPßCD to some of the patients in this case series. We thank the following participating physicians (in addition to the authors $\mathrm{CH}, \mathrm{CV}, \mathrm{RYW}, \mathrm{AC}, \mathrm{CL}$ ) who treated patients and submitted data for review and analysis in this case series:

Charles Lourenco, Marcela L. Almeida, Universidade de São Paulo, São Paulo, Brazil; Diane C. Williams, Ashland, OR, USA; Ellen Plummer, Asante Rogue Regional Medical Center, Medford, OR, USA.

We also thank the patients and their families for their willingness to be the first to participate in expanded access use studies and allow their data to gathered and analyzed so that we may learn from their experiences and someday find a cure for patients in the future.

Tribute: This paper is dedicated to our patients and their families whose spirits inspire us to understand this disease and find new treatments to improve their quality of life.

\section{Authors' contributions}

$\mathrm{CH}$ developed the first clinical protocol for treatment of NPC with HPßCD (Hastings-Hempel protocol 2008), developed the data acquisition protocol, consented patients and collected data, reviewed all submitted patient data for accuracy, consistency and completeness, performed data analyses and wrote the manuscript. CV obtained consent and data collection and provided manuscript edits. BL contributed to writing the manuscript. CB managed the data acquisition protocol, IRB submissions and consent process, and provided edits to the paper. CG organized the data, created spreadsheets, performed analyses, and developed the initial graphs. RYW and AC provided patient data and contributed to development of the figures and graphs. SH initiated and provided oversight in the data collection process, collected data, obtained patient consents for CTD, and contributed to the writing with the authors and with Prism. All the authors read and approved the final manuscript.

\section{Funding}

CTD Holdings, Inc. provided resources to develop CRFs utilized by the authors for data collection, supported travel and other costs for significant portions of data collection in Brazil and the US, and supported Dr. James Sawyer and Dr. Mike Parsons, Prism Ideas (UK), in developing the CRFs and the first draft of this manuscript.

\section{Availability of data and materials}

The data that support the findings of this study are available on reasonable request from the corresponding author and/or CTD Dr. Sharon Hrynkow. However, restrictions apply to the availability and use of these data, which were specifically requested for use in this review of compassionate use, and so are not publicly available.

Access to the initial Hastings/Hempel clinical protocol (2008) for compassionate use, and FDA filings, can be viewed online [57].

\section{Ethics approval and consent to participate}

A data acquisition protocol was developed by the lead author $(\mathrm{CH})$ and all investigators sought approval from local ethics or Institutional Review Boards. Case Report Forms (CRFs) were developed to capture patient characteristics including manifestations of disease, adverse events (AEs), details of drug administration, laboratory and clinical assessments. Informed consent was obtained from all of the subjects prior to the initiation of treatment with HPßCD in accordance to the local Institutional Review Boards and principles of ethical research according to the Declaration of Helsinki.

\section{Consent for publication}

Consent was obtained from the patient families by the investigators to participate in the data acquisition protocol with the intent to publish the results. 


\section{Competing interests}

Caroline Hastings: Principal Investigator, Phase I Study of the pharmacokinetics of Trappso ${ }^{\oplus} \mathrm{Cyclo}^{\mathrm{TM}}$ and effects on potential biomarkers of Niemann-Pick C1 (NPC1), ClinicalTrials.gov NCT02939547, CTD Holdings, Inc:; Senior clinical advisor and member of the Safety Review Committee EU Phase I/II Study of pharmacokinetics and preliminary efficacy of Trappsol ${ }^{\otimes} \mathrm{Cy}$ $\mathrm{Clo}^{\mathrm{TM}}$ in patients with Niemann-Pick C1 (NPC1), ClincialTrials.gov NCT02912793, CTD Holdings, Inc.; Co-Chair, Listening Circle, CTD Holdings, Inc.

\section{Camilo Vieira: None}

Benny Liu: Co-Principal Investigator, Phase I Study of the pharmacokinetics of Trappsol ${ }^{\oplus} \mathrm{Cyclo}^{\mathrm{TM}}$ and effects on potential biomarkers of Niemann-Pick C1 (NPC1); ClinicalTrials.gov NCT02939547, CTD Holdings, Inc.; Scientific Advisory Board, CTD Holdings, Inc.

Cyrus Bascon: Clinical research associate, Data Acquisition Study of Compassionate Use HPBCD, CTD Holdings, Inc.

\section{Claire Gao: None}

Raymond Wang: Local Site Principal Investigator, Study of VTS-270 (2-hydroxypropyl-beta-cyclodextrin) to treat Niemann-Pick Type C1 (NPC1) disease, ClinicalTrials.gov NCT02534844, Vtesse, Inc.; Scientific Advisory Board for NPC, Sucampo Pharmaceuticals, Inc.

\section{Alicia Casey: None}

Sharon Hrynkow: Chief Scientific Officer and Senior Vice President for Medical Affairs; Co-Chair, Listening Circle; Co-Chair, Scientific Advisory Board, CTD Holdings, Inc

\section{Author details}

'Department of Pediatric Hematology Oncology, UCSF Benioff Children's Hospital Oakland, 747 52nd Street, Oakland, CA 94609-1809, USA. ${ }^{2}$ Department of Pediatrics, University of California San Francisco, San Francisco, CA, USA. ${ }^{3}$ Universidade Federal da Bahia, Clínica Citta, Ed. Mundo Plaza, Av. Tancredo Neves, 620, Sala 1905, Camino dos Árvares, Salvador, Brazil. ${ }^{4} \mathrm{Gl}$ \& Liver Clinics, Highland Hospital, Alameda Health System, Highland Hospital, Oakland, CA, USA. ${ }^{5}$ Division of Gastroenterology \& Hepatology, Highland Hospital, Alameda Health Systems, Highland Care Pavilion 5th floor, 1411 East 31st Street, Oakland, CA 94602, USA. ${ }^{6}$ UCSF Benioff Children's Hospital Oakland, Oakland, CA, USA. ${ }^{7}$ Present Address: Neuroscience Graduate Program, Brown University, 185 Meeting Street, Box GL-N, Providence, RI 02912, USA. ${ }^{8}$ Division of Metabolic Disorders, Children's Hospital of Orange County, CHOC Children's Specialists, 1201 W. La Veta Ave, Orange, CA 92868, USA. ${ }^{9}$ Department of Pediatrics, University of California, Irvine School of Medicine, Irvine, CA 92868, USA. ${ }^{10}$ Boston Children's Hospital, 300 Longwood Avenue, Boston, MA 02115, USA. ${ }^{11}$ CTD Holdings, Inc., P.O. Box 1180, Alachua, FL 32616, USA.

Received: 10 June 2019 Accepted: 21 September 2019 Published online: 21 October 2019

\section{References}

1. Vanier MT. Niemann-Pick disease type C. Orphanet J Rare Dis. 2010;5:16.

2. Hendriksz CJ, Anheim M, Bauer P, Bonnot O, Chakrapani A, Corvol JC, et al. The hidden Niemann-Pick type $C$ patient: clinical niches for a rare inherited metabolic disease. Curr Med Res Opin. 2017:33(5):877-90.

3. Patterson MC, Hendriksz CJ, Walterfang M, Sedel F, Vanier MT, Wijburg F, et al. Recommendations for the diagnosis and management of NiemannPick disease type C: an update. Mol Genet Metab. 2012;106(3):330-44.

4. Patterson MC, Clayton $\mathrm{P}$, Gissen $\mathrm{P}$, Anheim M, Bauer $\mathrm{P}$, Bonnot $\mathrm{O}$, et al. Recommendations for the detection and diagnosis of Niemann-Pick disease type C: an update. Neurol Clin Pract. 2017:7(6):499-511.

5. Group N-CGW, Wraith JE, Baumgartner MR, Bembi B, Covanis A, Levade T, et al. Recommendations on the diagnosis and management of NiemannPick disease type C. Mol Genet Metab. 2009;98(1-2):152-65.

6. Garver WS, Francis GA, Jelinek D, Shepherd G, Flynn J, Castro G, et al. The National Niemann-Pick C1 disease database: report of clinical features and health problems. Am J Med Genet A. 2007;143A(11):1204-11.

7. Pentchev PG, Comly ME, Kruth HS, Vanier MT, Wenger DA, Patel S, et al. A defect in cholesterol esterification in Niemann-Pick disease (type C) patients. Proc Natl Acad Sci U S A. 1985:82(23):8247-51.

8. Patterson MC, Walkley SU. Niemann-Pick disease, type C and Roscoe Brady. Mol Genet Metab. 2017;120(1-2):34-7.
9. Ioannou YA. Guilty until proven innocent: the case of NPC1 and cholesterol. Trends Biochem Sci. 2005;30(9):498-505.

10. Vanier MT, Millat G. Niemann-Pick disease type C. Clin Genet. 2003;64(4):269-81.

11. Vanier MT, Latour P. Laboratory diagnosis of Niemann-Pick disease type C: the filipin staining test. Methods Cell Biol. 2015;126:357-75.

12. te Vruchte D, Lloyd-Evans E, Veldman RJ, Neville DC, Dwek RA, Platt FM, et al. Accumulation of glycosphingolipids in Niemann-Pick $C$ disease disrupts endosomal transport. J Biol Chem. 2004;279(25):26167-75.

13. Lloyd-Evans E, Platt FM. Lipids on trial: the search for the offending metabolite in Niemann-Pick type C disease. Traffic. 2010;11(4):419-28.

14. Patterson MC, Mengel E, Wijburg FA, Muller A, Schwierin B, Drevon $\mathrm{H}$, et al. Disease and patient characteristics in NP-C patients: findings from an international disease registry. Orphanet J Rare Dis. 2013;8:12.

15. Strupp M, Kremmyda O, Adamczyk C, Bottcher N, Muth C, Yip CW, et al. Central ocular motor disorders, including gaze palsy and nystagmus. J Neurol. 2014;261(Suppl 2):S542-58.

16. Sevin M, Lesca G, Baumann N, Millat G, Lyon-Caen O, Vanier MT, et al. The adult form of Niemann-Pick disease type C. Brain. 2007;130(Pt 1):120-33.

17. Abel LA, Walterfang M, Fietz M, Bowman EA, Velakoulis D. Saccades in adult Niemann-Pick disease type $C$ reflect frontal, brainstem, and biochemical deficits. Neurology. 2009:72(12):1083-6.

18. Solomon D, Winkelman AC, Zee DS, Gray L, Buttner-Ennever J. Niemann-Pick type $C$ disease in two affected sisters: ocular motor recordings and brain-stem neuropathology. Ann N Y Acad Sci. 2005;1039:436-45.

19. Walterfang M, Macfarlane MD, Looi JC, Abel L, Bowman E, Fahey MC, et al. Pontine-to-midbrain ratio indexes ocular-motor function and illness stage in adult Niemann-Pick disease type C. Eur J Neurol. 2012;19(3):462-7.

20. Karimzadeh P, Tonekaboni SH, Ashrafi MR, Shafeghati Y, Rezayi A, Salehpour $S$, et al. Effects of miglustat on stabilization of neurological disorder in niemann-pick disease type C: Iranian pediatric case series. J Child Neurol. 2013;28(12):1599-606.

21. Salsano E, Umeh C, Rufa A, Pareyson D, Zee DS. Vertical supranuclear gaze palsy in Niemann-Pick type C disease. Neurol Sci. 2012;33(6):1225-32.

22. Patterson MC, Vecchio D, Prady H, Abel L, Wraith JE. Miglustat for treatment of Niemann-Pick C disease: a randomised controlled study. Lancet Neurol. 2007:6(9):765-72.

23. Wijburg FA, Sedel F, Pineda M, Hendriksz CJ, Fahey M, Walterfang M, et al. Development of a suspicion index to aid diagnosis of Niemann-Pick disease type C. Neurology. 2012;78(20):1560-7.

24. Imrie J, Heptinstall L, Knight S, Strong K. Observational cohort study of the natural history of Niemann-Pick disease type C in the UK: a 5-year update from the UK clinical database. BMC Neurol. 2015;15:257.

25. Winstone AM, Stellitano LA, Verity CM. Niemann-Pick type $C$ as a cause of progressive intellectual and neurological deterioration in childhood. Dev Med Child Neurol. 2017;59(9):965-72.

26. Wraith JE, Guffon N, Rohrbach M, Hwu WL, Korenke GC, Bembi B, et al. Natural history of Niemann-Pick disease type $C$ in a multicentre observational retrospective cohort study. Mol Genet Metab. 2009;98(3):250-4.

27. Vanier MT. Niemann-Pick diseases. Handb Clin Neurol. 2013:113:1717-21.

28. Battisti C, Tarugi P, Dotti MT, De Stefano N, Vattimo A, Chierichetti F, et al. Adult onset Niemann-Pick type $C$ disease: a clinical, neuroimaging and molecular genetic study. Mov Disord. 2003;18(11):1405-9.

29. Trendelenburg G, Vanier MT, Maza S, Millat G, Bohner G, Munz DL, et al. Niemann-Pick type $C$ disease in a 68-year-old patient. J Neurol Neurosurg Psychiatry. 2006;77(8):997-8.

30. Schicks J, Muller Vom Hagen J, Bauer P, Beck-Wodl S, Biskup S, Krageloh-Mann I, et al. Niemann-Pick type $C$ is frequent in adult ataxia with cognitive decline and vertical gaze palsy. Neurology. 2013;80(12):1169-70.

31. Greenberg CR, Barnes JG, Kogan S, Seargeant LE. A rare case of Niemann-Pick disease type $C$ without neurological involvement in a 66-year-old patient. Mol Genet Metab Rep. 2015:3:18-20.

32. Mengel E, Pineda M, Hendriksz CJ, Walterfang M, Torres JV, Kolb SA. Differences in Niemann-Pick disease type C symptomatology observed in patients of different ages. Mol Genet Metab. 2017;120(3):180-9.

33. Degtyareva AV, Mikhailova SV, Zakharova EY, Tumanova EL, Puchkova AA. Visceral symptoms as a key diagnostic sign for the early infantile form of Niemann-Pick disease type C in a Russian patient: a case report. J Med Case Rep. 2016;10(1):143.

34. Evans WRH, Nicoli ER, Wang RY, Movsesyan N, Platt FM. Case report: Ursodeoxycholic acid treatment in Niemann-Pick disease type $C_{\text {; }}$ clinical experience in four cases. Wellcome Open Res. 2017;2:75. 
35. Hegarty R, Hadzie N, Gissen P, Dhawan A. Inherited metabolic disorders presenting as acute liver failure in newborns and young children: King's College Hospital experience. Eur J Pediatr. 2015;174:1387-92.

36. von Ranke FM, Pereira Freitas HM, Mancano AD, Rodrigues RS, Hochhegger B, Escuissato D, et al. Pulmonary involvement in Niemann-Pick disease: a state-of-the-art review. Lung. 2016;194(4):511-8.

37. Palmeri S, Tarugi P, Sicurelli F, Buccoliero R, Malandrini A, De Santi MM, et al. Lung involvement in Niemann-Pick disease type C1: improvement with bronchoalveolar lavage. Neurol Sci. 2005;26(3):171-3.

38. Staretz-Chacham O, Aviram M, Morag I, Goldbart A, Hershkovitz E. Pulmonary invovlement in Niemann-Pick C type 1. Eur J Pediatr. 2018. 177(11):1609-15.

39. Patterson MC, Mengel E, Vanier MT, Schwierin B, Muller A, Cornelisse $P$, et al. Stable or improved neurological manifestations during miglustat therapy in patients from the international disease registry for Niemann-Pick disease type C: an observational cohort study. Orphanet J Rare Dis. 2015;10:65.

40. Galanaud D, Tourbah A, Lehericy S, Leveque N, Heron B. Billette de Villemeur T, et al. 24 month-treatment with miglustat of three patients with Niemann-Pick disease type C: follow up using brain spectroscopy. Mol Genet Metab. 2009;96(2):55-8.

41. Pineda M, Wraith JE, Mengel $E_{1}$ Sedel F, Hwu WL, Rohrbach M, et al. Miglustat in patients with Niemann-Pick disease type C (NP-C): a multicenter observational retrospective cohort study. Mol Genet Metab. 2009;98(3):243-9.

42. Pineda M, Perez-Poyato MS, O'Callaghan M, Vilaseca MA, Pocovi M, Domingo $\mathrm{R}$, et al. Clinical experience with miglustat therapy in pediatric patients with Niemann-Pick disease type C: a case series. Mol Genet Metab. 2010;99(4):358-66

43. Fecarotta S, Romano A, Della Casa R, Del Giudice E, Bruschini D, Mansi G, et al. Long term follow-up to evaluate the efficacy of miglustat treatment in Italian patients with Niemann-Pick disease type C. Orphanet J Rare Dis. 2015;10:22.

44. Wraith JE, Vecchio D, Jacklin E, Abel L, Chadha-Boreham H, Luzy C, et al. Miglustat in adult and juvenile patients with Niemann-Pick disease type C: long-term data from a clinical trial. Mol Genet Metab. 2010;99(4):351-7.

45. Wraith JE, Imrie J. New therapies in the management of Niemann-Pick type C disease: clinical utility of miglustat. Ther Clin Risk Manag. 2009;5:877-87.

46. Yanjanin NM, Velez Jl, Gropman A, King K, Bianconi SE, Conley SK, et al. Linear clinical progression, independent of age of onset, in Niemann-Pick disease, type C. Am J Med Genet B Neuropsychiatr Genet. 2010;153B(1):132-40.

47. Ginocchio VM, D'Amico A, Bertini E, Ceravolo F, Dardis A, Verrigni D, et al. Efficacy of miglustat in Niemann-Pick $C$ disease: a single centre experience. Mol Genet Metab. 2013;110(3):329-35.

48. Brewster ME, Loftsson T. Cyclodextrins as pharmaceutical solubilizers. Adv Drug Deliv Rev. 2007;59(7):645-66.

49. Loftsson T, Brewster ME. Cyclodextrins as functional excipients: methods to enhance complexation efficiency. J Pharm Sci. 2012;101(9):3019-32.

50. Griffin LD, Gong W, Verot L, Mellon SH. Niemann-Pick type C disease involves disrupted neurosteroidogenesis and responds to allopregnanolone. Nat Med. 2004;10(7):704-11.

51. Ahmad I, Lope-Piedrafita S, Bi X, Hicks C, Yao Y, Yu C, et al. Allopregnanolone treatment, both as a single injection or repetitively, delays demyelination and enhances survival of Niemann-Pick C mice. J Neurosci Res. 2005;82(6):811-21.

52. Langmade SJ, Gale SE, Frolov A, Mohri I, Suzuki K, Mellon SH, et al. Pregnane $X$ receptor (PXR) activation: a mechanism for neuroprotection in a mouse model of Niemann-Pick C disease. Proc Natl Acad Sci U S A. 2006; 103(37):13807-12.

53. Liu B, Li H, Repa JJ, Turley SD, Dietschy JM. Genetic variations and treatments that affect the lifespan of the NPC1 mouse. J Lipid Res. 2008; 49(3):663-9

54. Camargo F, Erickson RP, Garver WS, Hossain GS, Carbone PN, Heidenreich RA, et al. Cyclodextrins in the treatment of a mouse model of Niemann-Pick C disease. Life Sci. 2001;70(2):131-42.

55. Liu B, Turley SD, Burns DK, Miller AM, Repa JJ, Dietschy JM. Reversal of defective lysosomal transport in NPC disease ameliorates liver dysfunction and neurodegeneration in the npc1-/- mouse. Proc Natl Acad Sci U S A. 2009:106(7):2377-82

56. Taylor AM, Liu B, Mari Y, Liu B, Repa JJ. Cyclodextrin mediates rapid changes in lipid balance in Npc1-/- mice without carrying cholesterol through the bloodstream. J Lipid Res. 2012;53(11):2331-42.
57. Ramirez CM, Liu B, Taylor AM, Repa JJ, Burns DK, Weinberg AG, et al. Weekly cyclodextrin administration normalizes cholesterol metabolism in nearly every organ of the Niemann-Pick type C1 mouse and markedly prolongs life. Pediatr Res. 2010;68(4):309-15.

58. Available from: http://addiandcassi.com/category/cyclodextrin/fdacyclodextrin-filings/.

59. Tanaka Y, Yamada Y, Ishitsuka Y, Matsuo M, Shiraishi K, Wada K, et al. Efficacy of 2-hydroxypropyl-beta-cyclodextrin in Niemann-Pick disease type $\mathrm{C}$ model mice and its pharmacokinetic analysis in a patient with the disease. Biol Pharm Bull. 2015;38(6):844-51.

60. Vite CH, Bagel JH, Swain GP, Prociuk M, Sikora TU, Stein VM, et al. Intracisternal cyclodextrin prevents cerebellar dysfunction and Purkinje cell death in feline Niemann-Pick type C1 disease. Sci Transl Med. 2015;7(276):276ra26.

61. Davidson CD, Ali NF, Micsenyi MC, Stephney G, Renault S, Dobrenis K, et al. Chronic cyclodextrin treatment of murine Niemann-Pick $C$ disease ameliorates neuronal cholesterol and glycosphingolipid storage and disease progression. PLoS One. 2009;4(9):e6951.

62. World Medical A. World medical association declaration of Helsinki: ethical principles for medical research involving human subjects. JAMA. 2013; 310(20):2191-4

63. Atger VM, de la Llera Moya M, Stoudt GW, Rodrigueza WV, Phillips MC, Rothblat $\mathrm{GH}$. Cyclodextrins as catalysts for the removal of cholesterol from macrophage foam cells. J Clin Invest. 1997;99(4):773-80

64. Peake KB, Vance JE. Normalization of cholesterol homeostasis by 2-hydroxypropylbeta-cyclodextrin in neurons and glia from Niemann-Pick C1 (NPC1)-deficient mice. J Biol Chem. 2012;287(12):9290-8.

65. Aqul A, Liu B, Ramirez CM, Pieper AA, Estill SJ, Burns DK, et al. Unesterified cholesterol accumulation in late endosomes/lysosomes causes neurodegeneration and is prevented by driving cholesterol export from this compartment. J Neurosci. 2011;31(25):9404-13.

66. Ramirez CM, Liu B, Aqul A, Taylor AM, Repa JJ, Turley SD, et al. Quantitative role of $L A L, N P C 2$, and NPC1 in lysosomal cholesterol processing defined by genetic and pharmacological manipulations. J Lipid Res. 2011;52(4):688-98.

67. Iturriaga C, Pineda M, Fernandez-Valero EM, Vanier MT, Coll MJ. Niemann-Pick C disease in Spain: clinical spectrum and development of a disability scale. J Neurol Sci. 2006:249(1):1-6.

68. Vanier MT, Gissen P, Bauer P, Coll MJ, Burlina A, Hendriksz CJ, et al. Diagnostic tests for Niemann-Pick disease type C (NP-C): a critical review. Mol Genet Metab. 2016;118(4):244-54.

69. Giese AK, Mascher H, Grittner U, Eichler S, Kramp G, Lukas J, et al. A novel, highly sensitive and specific biomarker for Niemann-Pick type C1 disease. Orphanet J Rare Dis. 2015;10:78.

70. Polo G, Burlina AP, Kolamunnage TB, Zampieri M, Dionisi-Vici C, Strisciuglio $P$, et al. Diagnosis of sphingolipidoses: a new simultaneous measurement of lysosphingolipids by LC-MS/MS. Clin Chem Lab Med. 2017;55(3):403-14.

71. Welford RW, Garzotti M, Marques Lourenco C, Mengel E, Marquardt T, Reunert J, et al. Plasma lysosphingomyelin demonstrates great potential as a diagnostic biomarker for Niemann-Pick disease type $\mathrm{C}$ in a retrospective study. PLoS One. 2014;9(12):e114669.

72. Noda T, Todani T, Watanabe Y, Yamamoto S. Liver volume in children measured by computed tomography. Pediatr Radiol. 1997;27(3):250-2

73. Muralidhar A, Borbon IA, Esharif DM, Ke W, Manacheril R, Daines M, et al. Pulmonary function and pathology in hydroxypropyl-beta-cyclodextin-treated and untreated Npc1(-)/(-) mice. Mol Genet Metab. 2011;103(2):142-7.

74. Pontikis CC, Davidson CD, Walkley SU, Platt FM, Begley DJ. Cyclodextrin alleviates neuronal storage of cholesterol in Niemann-Pick $C$ disease without evidence of detectable blood-brain barrier permeability. J Inherit Metab Dis. 2013;36(3):491-8.

75. Vecsernyes M, Fenyvesi F, Bacskay I, Deli MA, Szente L, Fenyvesi E. Cyclodextrins, blood-brain barrier, and treatment of neurological diseases. Arch Med Res. 2014;45(8):711-29.

76. Coisne C, Tilloy S, Monflier E, Wils D, Fenart L, Gosselet F. Cyclodetrins as emerging therapeutic tools in the treatment of cholesterolassociated vascular and neurodegenrative diseases. Molecules. 2016; 21(12):1748

77. Rosenbaum Al, Zhang G, Warren JD, Maxfield FR. Endocytosis of betacyclodextrins is responsible for cholesterol reduction in Niemann-Pick type C mutant cells. Proc Natl Acad Sci U S A. 2010;107(12):5477-82.

78. Rosenbaum Al, Maxfield FR. Niemann-Pick type C disease: molecular mechanisms and potential therapeutic approaches. J Neurochem. 2011; 116(5):789-95. 
79. Vance JE, Peake KB. Function of the Niemann-Pick type $C$ proteins and their bypass by cyclodextrin. Curr Opin Lipidol. 2011;22(3):204-9.

80. Vite C, Mauldin E, Ward S, Stein V, Prociuk M, Haskins ME, et al. Intrathecal cyclodextrin therapy of feline Niemann-Pick type $\mathrm{C}$ disease. Mol Genet Metab. 2011;102(2):S44

81. Davidson CD, Fishman YI, Puskas I, Szeman J, Sohajda T, McCauliff LA, et al. Efficacy and ototoxicity of different cyclodextrins in Niemann-Pick $C$ disease. Ann Clin Transl Neurol. 2016;3(5):366-80.

82. Matsuo M, Togawa M, Hirabaru K, Mochinaga S, Narita A, Adachi M, et al. Effects of cyclodextrin in two patients with Niemann-Pick type $C$ disease. Mol Genet Metab. 2013;108(1):76-81.

83. Matsuo M, Shraishi K, Wada K, Ishitsuka Y, Doi H, Maeda M, et al. Effects of intracerebroventricular administration of 2-hydroxypropyl- $\beta$-cyclodextrin in a patient with Niemann-Pick type C disease. Mol Genet Metab Rep. 2014;1:391-400.

84. Garcia-Robles AA, Company-Albir MJ, Megias-Vericat JE, Fernandez-Megia MJ, Perez-Miralles FC, Lopez-Briz E, et al. Use of 2 hydroxypropyl-beta-cyclodextrin therapy in two adult Niemann Pick type C patients. J Neurol Sci. 2016;366:65-7.

85. Maarup TJ, Chen AH, Porter FD, Farhat NY, Ory DS, Sidhu R, et al. Intrathecal 2-hydroxypropyl-beta-cyclodextrin in a single patient with Niemann-Pick C1. Mol Genet Metab. 2015;116(1-2):75-9.

86. Megias-Vericat JE, Garcia-Robles A, Company-Albir MJ, Fernandez-Megia MJ, Perez-Miralles FC, Lopez-Briz E, et al. Early experience with compassionate use of 2 hydroxypropyl-beta-cyclodextrin for Niemann-Pick type C disease: review of initial published cases. Neurol Sci. 2017;38(5):727-43.

87. Schwerd T, Pandey S, Yang HT, Bagola K, Jameson E, Jung J, et al. Impaired antibacterial autophagy links granulomatous intestinal inflammation in Niemann-Pick disease type $\mathrm{C} 1$ and XIAP deficiency with NOD2 variants in Crohn's disease. Gut. 2017;66(6):1060-73.

88. Amiri M, Kuech EM, Shammas H, Wetzel G, Naim HY. The Pathobiochemistry of gastrointestinal symptoms in a patient with Niemann-Pick type C disease. JIMD Rep. 2016;25:25-9.

89. Cortina-Borja M, Te Vruchte D, Mengel E, Amraoui Y, Imrie J, Jones SA, et al. Annual severity increment score as a tool for stratifying patients with Niemann-Pick disease type $C$ and for recruitment to clinical trials. Orphanet J Rare Dis. 2018;13(1):143.

90. Vanier MT, Wenger DA, Comly ME, Rousson R, Brady RO, Pentchev PG. Niemann-Pick disease group C: clinical variability and diagnosis based on defective cholesterol esterification. A collaborative study on 70 patients. Clin Genet. 1988;33(5):331-48.

91. Vanier MT, Rodriguez-Lafrasse C, Rousson R, Gazzah N, Juge MC, Pentchev PG, et al. Type C Niemann-Pick disease: spectrum of phenotypic variation in disruption of intracellular LDL-derived cholesterol processing. Biochim Biophys Acta. 1991;1096(4):328-37.

92. Walterfang M, Fietz M, Abel L, Bowman E, Mocellin R, Velakoulis D. Gender dimorphism in siblings with schizophrenia-like psychosis due to Niemann-Pick disease type C. J Inherit Metab Dis. 2009;32(Suppl 1):S221-6.

\section{Publisher's Note}

Springer Nature remains neutral with regard to jurisdictional claims in published maps and institutional affiliations.

Ready to submit your research? Choose BMC and benefit from:

- fast, convenient online submission

- thorough peer review by experienced researchers in your field

- rapid publication on acceptance

- support for research data, including large and complex data types

- gold Open Access which fosters wider collaboration and increased citations

- maximum visibility for your research: over $100 \mathrm{M}$ website views per year

At $\mathrm{BMC}$, research is always in progress.

Learn more biomedcentral.com/submissions 